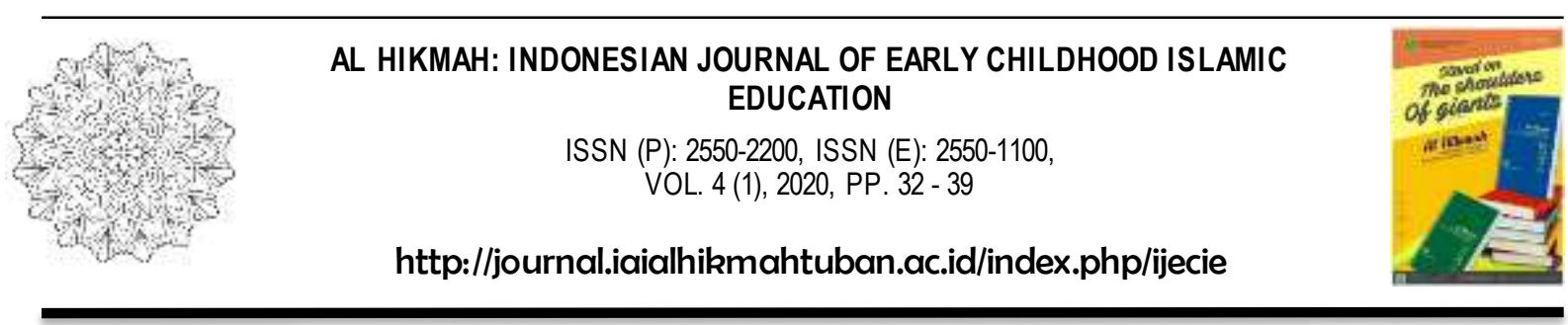

\title{
PERUBAHAN POLA HDUP ANAK SEBELUM DAN SELAMA PANDEMI COVID-19
}

\author{
Sri Widayati ${ }^{1}$, Wulan Patria $^{2}$, Irma Novita ${ }^{3}$ \\ ${ }^{1,2,3}$ Pendidikan Guru Pendidikan Anak Usia Dini, Fakultas Ilmu Pendidikan, Universitas Negeri Surabaya \\ sriwadayati@gmail.unesa.com
}

\begin{abstract}
Abstrak
Dunia sangat disibukkan oleh pandemic covid 19 sehingga berdampak pada aspek kehidupan, terrutama pada pola kehidupan anak. Penelitian ini bertujuan untuk mengetahui perbedaan pola hidup anak usia dini terkait sebelum dan selama pandemic covid-19. Sebanyak 381 anak usia dini menjadi sasaran pada penelitian ini. Pendekatan yang digunakan pada penelitian yaitu pendekatan kuantitatif dengan jenis analisis survey. Pengumpulan data pada penelitian ini dengan teknik kuisioner online dengan skala likert. Teknik analisis pada penelitian ini menggunakan uji paired sample $t$ test. Hasil penelitian menunjukkan adanya transisi terkait perubahan pola hidup anak usia dini sebelum dan selama pandemic covid-19. Penelitian ini memberikan impikasi agar orang tua lebih terlibat dalam penyesuain pola hidup anak saat pandemic covid-19.
\end{abstract}

Kata Kunci: pola hidup anak, covid-19

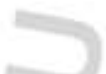

\section{Abstract}

The world is so preoccupied by pandemic covid 19 that it has an impact on aspects of life, especially on children's life patterns. This study aims to determine differences in life patterns of early childhood related before and during the co-19 pandemic. A total of 381 early childhoods were targeted in this study. The approach used in research is a quantitative approach to the type of survey analysis. Collecting data in this study with online questionnaire techniques with a Likert scale. The analysis technique in this study used paired sample $t$ test. The results showed a transition related to changes in lifestyle of early childhood before and during the co-19 pandemic. This study provides the impression that parents are more involved in adjusting children's lifestyles during the co-19 pandemic.

Keywords: child lifestyle, covid-19 


\section{PENDAHULUAN}

Saat ini, dunia sedang disibukkan dengan adanya pandemic Covid-19. Terhitung tanggal 26 Mei 2020 jumlah kematian 384,760 jiwa virus ini telah menginfeksi 5,623,503 orang serta sebanyak 213 negara (worddometers.info, 2020). Di Indonesia jumlah yang terkena covid pada bulan April jumlah kasus postif covid-19 mencapai 1,667 jiwa, sehingga semakin meluas dan menyebabkan pemerintah membuat aturan mengenai WFH. Melalui Surat Edaran No. 3 tahun 2020 (Kemendikbud, 2020) dan Surat Edaran No. 4 tahun 2020 yang dikeluarkan oleh Menteri Pendidikan dan Kebudayaan RI ada beberapa kebijakan yang berdampak pada semua aspek kehidupan, termasuk didalamnya adalah pola hidup anak.

Arti dari pola hidup adalah menurut Mubyarto (1988: 115) suatu kebiasaan yang terjadi secara kontinyu atau terus menerus dalam hidup seseorang. Pola hidup sangat berkaitan erat dengan runtutan aktivitas yang dilakukan oleh seorang manusia dalam kehidupannya seharihari. Pola hidup orang dewasa dengan pola hidup anak usia dini tentu saja berbeda. Di mana anak usia dini masih memiliki porsi bermain yang lebih banyak dibandingkan orang dewasa, memiliki lebih sedikit tanggung jawab, lebih banyak diarahkan oleh orang tua dalam mengambil keputusan, dan lain sebagainya.

Pengaturan pola hidup dalam hal ini meliputi pola makan, tidur, olahraga/ bergerak. Pola makan mempunyai arti suatu kebiasaan menetap dalam hubungan dengan konsumsi makanan berupa makanan pokok, sumber protein, sayuran, buah-buahan dan susu (Auliah et al., 2020). Pola tidur yang singkat juga mempengaruh pada pola makan, karena peningkatan grehlin dan penurunan resitensi leptin. (Relda, 2013). Pola konsumsi yang diterapkan pada anak adalah makanan yang tinggi energi namun sedikit mengandung serat. (Rahayuningtyas, 2012).

Anak usia dini yaitu individu yang mengalami proses perkembangan yang menyeluruh dan fundamental bagi kehidupan selanjutnya (Sujiyono, 2009:6). Setiap anak bersifat unik, setiap anak mewarisi sifat orang tua dan tumbuh dari pengaruh lingkungan sekitarnya. Pengaruh dari lingkungan inilah yang berdampak pada pola hidup seorang anak. Pola hidup seorang anak terbentuk karena pembiasaan. Stimulasi secara berulang membuat suatu kebiasaan menjadi melekat pada diri seorang manusia. Terkadang jika kebiasaan tersebut tidak dilakukan akan membuat seorang individu merasakan ada yang hilang.

Pendapat lain oleh Prayitno (2010:3) menyatakan anak usia dini adalah anak yang berada pada rentang usia 0-6 tahun yang berada dalam proses pertumbuhan dan perkembangan yang menakjubkan, anak berinteraksi bergantung pada kemampuannya untuk menguasai perkembangannya. Pada rentang usia 3-6 tahun adalah masa anak memasuki masa pra- 
Sri Widayati, Wulan Patria, Irma Novita (Perubahan Pola Hidup Anak)

sekolah untuk mempersiapkan masuk pendidikan formal. Masa ini adalah masa peka anak terhadap segala rangsangan yang diterima melalui panca indera anak. pemberian rangsangan yang baik akan mengalami peningkatan pada tumbuh kembang yang sesuai dengan usianya. Adanya pandemic covid-19, pola hidup anak banyak sekali perbedaan. Diantaranya anak yang yang melakukan kegiatan belajar dengan tatap muka dengan guru, sekarang berubah menjadi belajar dari rumah. Pola bermain umumnya anak keluar rumah bersama teman sebayanya selama covid ini menjadi lebih cendrung dilakukan di dalam rumah, pola makan di rumah yang sebelum covid kegiatan makan ada waktu makan di rumah dan diluar rumah namun pada covid pola makan anak cenrung semua di lakukan didalam rumah. Banyak hal lainnya terkait dengan kativitas anak yang awalnya sebagian terbagi antara rumah dan luar rumah namun selama pandemic covid ini semua cendrung di lakukan di dalam rumah.

Adanya situasi seperti ini membuat peneliti ingin melihat sejauh mana pola hidup anak dengan keadaan sebelum dan selama pandemic Covid-19. Apakah ada perubahan yang mencolok sekali atau tidak.

\section{METODE}

Penelitian ini menggunakan desain lintas sektoral (cross section design) yang merupakan rancangan penelitian dan pengamatannya dilakukan pada satu waktu dengan tujuan menggambarkan populasi yang ada. Populasi pada penelitian menggunakan 381 anak di Indonesia. Penelitian ini menggunakan teknik kuisioner online berupa google form yang mampu diakses oleh siapa saja dan memberikan sejumlah butir pernyataan tentang pola hidup anak sebelum dan selama masa pandemic Covid-19 ini. Kuisioner yang digunakan adalah kuisioner tertutup, sehingga jawaban yang sudah tersedia dan responen tinggal memilih jawabnnya,

Instrumen ini mneggunakan skala likert, dimana angka 1 mewakili jawaban 'tidak pernah', 2 mewakili jawaban 'jarang', 3 mewakili jawaban 'sering', 4 mewakili jawaban 'selalu'. Skor total akan diperoleh dengan menghitung rata-rata dari jawaban responden terhadap 30 pertanyaan yang diberikan. Analisis data pada penelitian ini dilakukan dari tahap uji vailiditas, uji reliabilitas, uji normalitas, uji homogenitas. Selanjutnya dilakukan analisis data uji paired sample t-test untuk mengetahui perbedaan pola hidup anak sebelum dan selama pandemic Covid-19.

Pengambilan keputusan uji paired sample t test sebagai berikut: 
Sri Widayati, Wulan Patria, Irma Novita (Perubahan Pola Hidup Anak)

1. Jika nilai sig > 0,05, maka Ho diterima dan Ha ditolak artinya tidak ada perbedaan rata-rata pola hidup anak sebelum dan selama pandemi covid 19

2. Jika nilai sig $<0,05$ maka maka Ho ditolak dan Ha diterima artinya ada perbedaan rata-rata pola hidup anak sebelum dan selama pandemi covid 19.

\section{HASIL DAN PEMBAHASAN}

Berdasarkan data yang dikumpulkan berikut ini adalah bagian dari google form yang telah digunakan untuk mendapatkan hasil penelitian yang akan diuraikan dibawah ini :

\section{SI? 2 UNESA \\ Selama Masa Pandemi Covid-19 \\ Partisipan sekalian yano kami hormati \\ terima kasih atas kasediaan Anda \\ berpartisipasi dalam penelitian kami \\ Perkenalkan, kami dari Tim Peneliti PG \\ PAUD Unesa, Surabaya \\ जamudi 1, Nuisıuner urmme}

Berikut link yang digunakan pada google form :

\section{https://forms.gle/oGjN8VMb9NQ4JETu5}

Sasaran pada penelitian ini berjumlah 381 anak usia dini di Indonesia yang disebar menggunakan kuisioner online melalui google form. Perhitungan uji validitas ini menggunakan software IBM SPSS versi 22. Berikut hasil validitas :

Tabel 1. Uji validitas

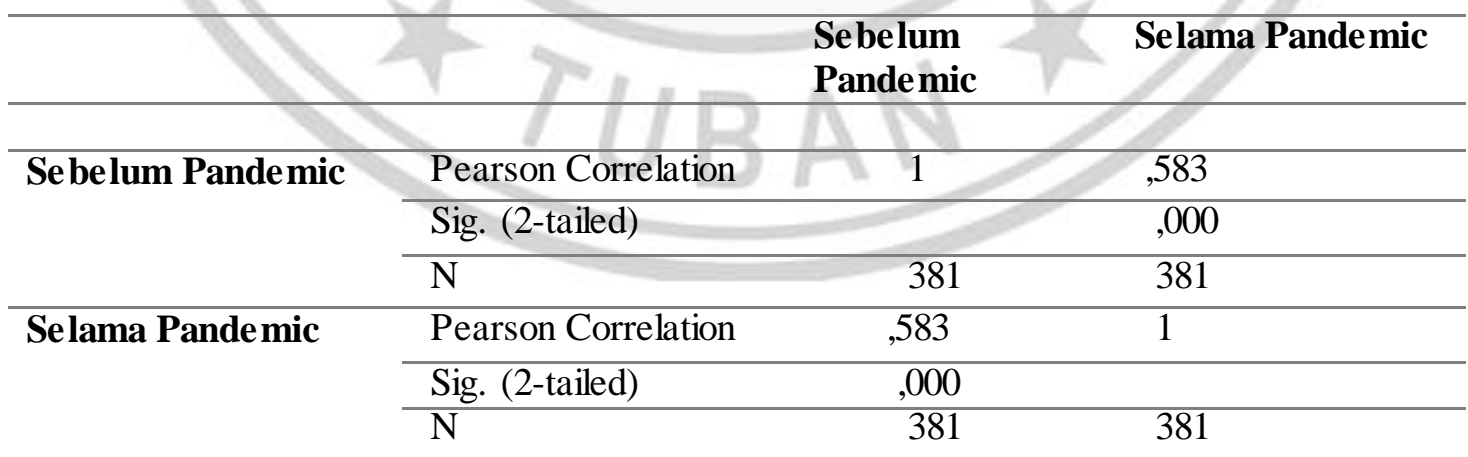

Pengambilan keputusan uji validitas sebagai berikut:

1) Jika nilai $r$ hitung > $r$ tabel, maka dinyatakan valid

2) Jika nilai $r$ hitung < r tabel, maka dinyatakan tidak valid 
Sri Widayati, Wulan Patria, Irma Novita (Perubahan Pola Hidup Anak)

Uji validitas ini menggunakan rumus korelasi product moment. Uji validitas pada masingmasing pertanyaan pola hidup anak sebelum dan sesudah pandemic Covid-19 dinyatakan valid. Pada masing-masing item memiliki nilai $r$ di atas 0,11 . Nilai $r$ hitung pada masing-masing butir pertanyaan $>$ dari $\mathrm{r}$ tabel $(0,11)$. Pada tabel tersebut $\mathrm{r}$ hitung $>\mathrm{r}_{\text {tabel }}$ sehingga data yang diperoleh yaitu masing-masing nomor item pernyataan dan butir indikator dinyatakan valid.

Tabel 2. Uji Reliabilitas

\begin{tabular}{cc}
\hline & Cronbach'Alpha \\
\hline Sebelum Pandemic &, 674 \\
\hline Selama Pandemic &, 673 \\
\hline
\end{tabular}

Uji reliabilitas pada penelitian ini menggunakan rumus cronbach' alpha dengan hasil variabel sebelum dan selama pandemic menunjukkan bahwa nilai koefisien cronbach' alpha di atas 0,6 yang artinya reliabel.

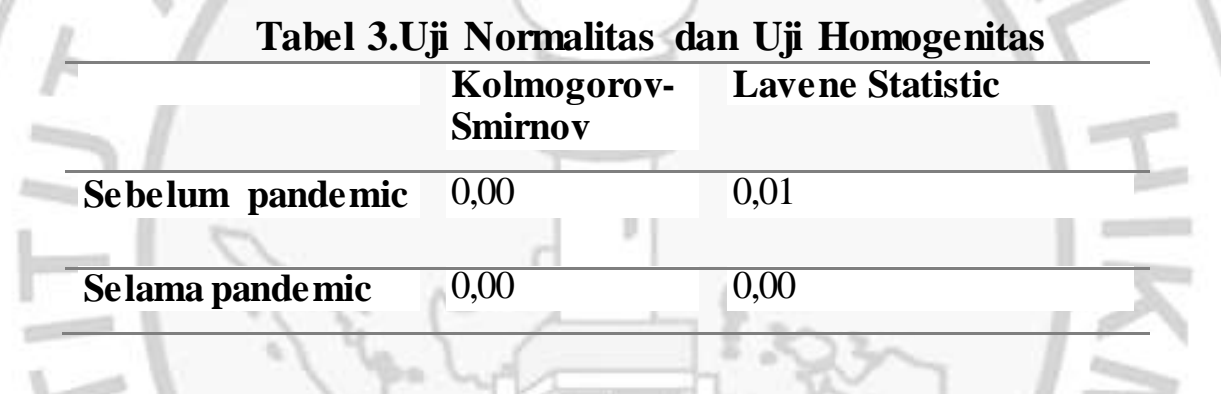

Berdasarkan uji normalitas kolmogrov-smirnov nilai yang diperoleh, maka data tersebut berdistribusi normal. Hasil uji homogenitas menyatakan data variabel bahasa adalah homogen. Setelah dilakukan Uji Asumsi Klasik, maka dilanjutkan dengan uji paired sample $t$ test.

Tabel 4. Uji Paired Sample t- Test

\begin{tabular}{lcccccc}
\hline & Mean & $\mathbf{N}$ & $\begin{array}{c}\text { Std. } \\
\text { Deviation }\end{array}$ & $\begin{array}{c}\text { Std. Error } \\
\text { Mean }\end{array}$ & Correlation & Sig \\
\cline { 1 - 5 } $\begin{array}{l}\text { Sebelum } \\
\text { Pandemic }\end{array}$ & 57,18 & 381 & 5,409 &, 277 &, 638 &, 000 \\
$\begin{array}{l}\text { Selama } \\
\text { Pandemic }\end{array}$ & 58,82 & 381 & 5,164 &, 265 & & \\
\hline
\end{tabular}

Berdasarkan hasil perhitungan di atas, dapat dïntrepetasikan ringkasan hasil statistik deskriptif dari kedua sampel yang diteliti yakni nilai sebelum dan selama pandemic. Untuk nilai sebelum pandemic diperoleh rata-rata gambaran pola anak atau mean sebesar 57,18. Sedangkan untuk nilai selama pandemic diperoleh rata-rata gambaran pola anak atau mean sebesar 58,82. Jumlah responden pada penelitian ini sebanyak 381 anak. Untuk nilai 
Sri Widayati, Wulan Patria, Irma Novita (Perubahan Pola Hidup Anak)

std.deviasi pada sebelum pandemic sebesar 5,409 dan pada nilai std.deviasi pada selama pandemic sebesar 5,164.

Output di atas menunjukkan hasil korelasi atau hubungan antara kedua data atau hubungan variabel sebelum dan selama pandemic. Berdasarkan nilai di atas diketahui nilai koefisien korelasi sebesar 0,638 dengan nilai sig sebesar 0,000. Berdasarkan nilai sig 0,000 < probabilitas 0,05, maka Ho ditolak dan Ha diterima. Dari data tersebut dapat disimpulkan ada perbedaan hubungan antara variabel pretest dan posttest, artinya ada pengaruh perbedaan pola hidup anak sebelum dan selama pandemi Covid 19.

Tabel 5 Perbedaan Pola Hidup

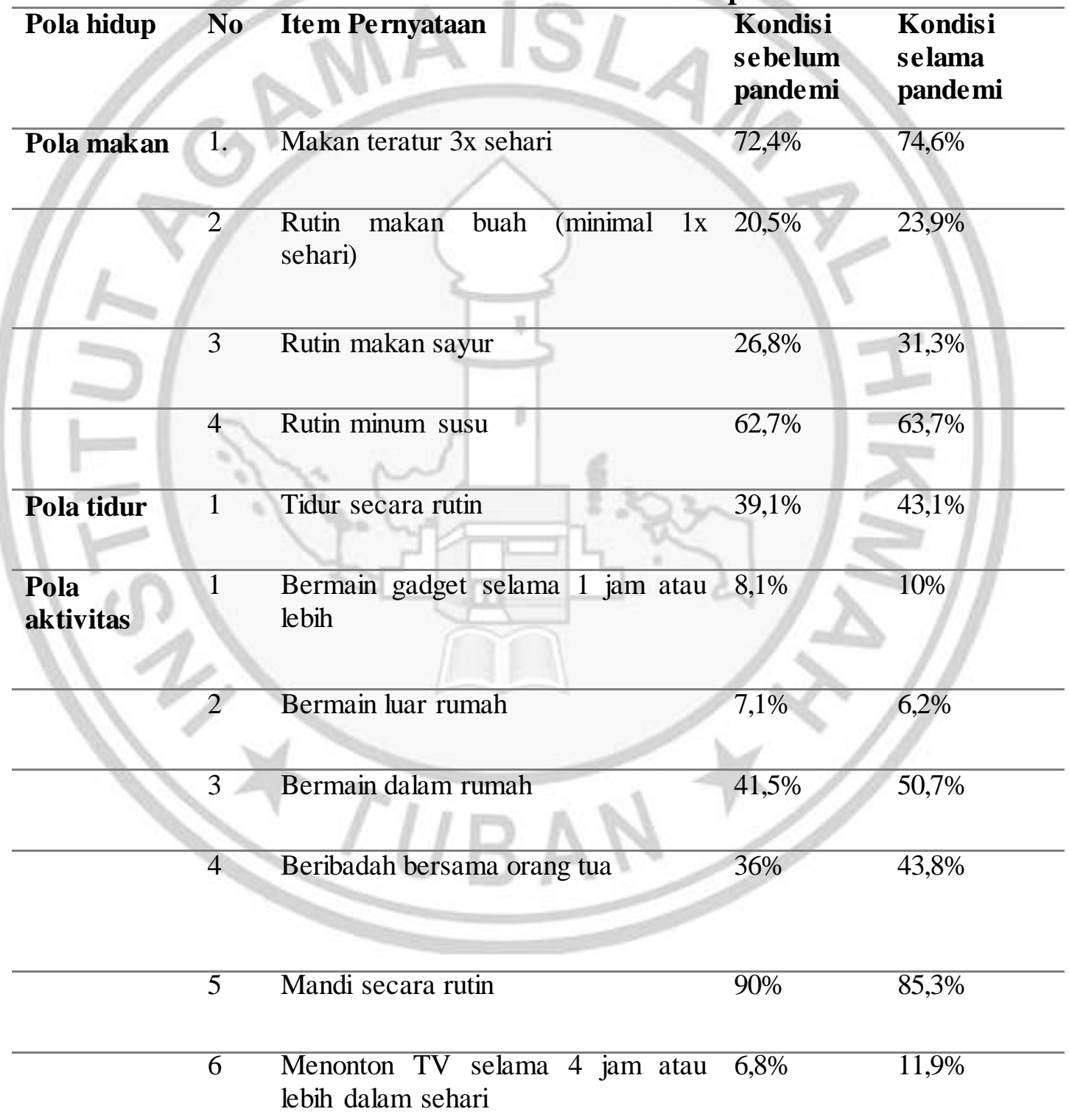


Sri Widayati, Wulan Patria, Irma Novita (Perubahan Pola Hidup Anak)

Berdasarkan data diatas, terdapat perbedaan yang signifikan terhadap pola hidup meliputi pola makan, pola tidur dan pola aktivitas anak sebelum dan selama pandemic. Pola makan meliputi makan teratur $3 x$ sehari sebelum pandemic sebanyak $72,4 \%$ dan selama pandemic sebanyak 74,6\%, rutin makan buah minimal 1x sehari sebelum pandemic sebanyak $20,5 \%$ dan selama pandemic $23,9 \%$, rutin makan sayur sebelum pandemic sebanyak $26,8 \%$ dan selama pandemic sebanyak $31,3 \%$, rutin minum susu sebelum pandemic sebanyak $62,7 \%$ dan selama pandemic sebanyak 63,7\%. Pola tidur secara rutin sebelum pandemic sebanyak $39,1 \%$ dan selama pandemic sebanyak $43,1 \%$. Pola aktivitas meliputi bermain gadget selama sejam atau lebih sebelum pandemic sebanyak $8,1 \%$ dan selama pandemic sebanyak $10 \%$, bermain luar rumah sebelum pandemic sebanyak $7,1 \%$ dan selama pandemic sebanyak $6,2 \%$, bermain dalam rumah sebelum pandemic sebanyak $41,5 \%$ dan selama pandemic sebanyak $50,7 \%$, beribadah bersama orang tua sebelum pandemic sebanyak $36 \%$ dan selama pandemic sebanyak 43,8\%, mandi secara rutin sebelum pandemic sebanyak $90 \%$ dan selama pandemic sebanyak $85,3 \%$, menonton TV selama 4 jam atau lebih dalam sehari sebelum pandemic sebanyak $6,8 \%$ dan selama pandemic sebanyak $11,9 \%$.

\section{PENUTUP}

\section{Simpulan}

Dunia disibukkan oleh wabah pandemic covid 19, jumlah kasus positif covid-19 terus bertambah. Dengan adanya masalah seperti ini pemerintah mengeluarkan kebijakan stay at home dengan semua kegiatan dari rumah, dimulai belajar dan bekerja dari rumah. Adanya situasi seperti para anak, guru dan masyarakat untuk menyesuaikan aktivitas dengan adanya pandemic covid-19, yang berdampak pada pola hidup anak saat ini. Hasil penelitian ini menyatakan bahwa terdapat signifikansi peningkatan perbedaan pola hidup anak terkait sebelum dan selama pandemic covid-19. Penelitian ini memberikan implikasi kepada orang tua untuk terlibat dalam pola hidup anak. Orang tua harus lebih memberikan keteladanan dan aturan yang lebih jelas agar pola hidup cendrung sudah baik pada anak terus melekat. 


\section{DAFTAR PUSTAKA}

Auliah, A. N., Hidayati, E. N., Yusup, I. R., \& Hidup, P. (2020). Hubungan pola hidup dan berat badan mahasiswa pendidikan biologi semester 7a. Bio Education, 5(April), 24-29.

Kementrian Pendidikan dan Kebudayaan Republik Indonesia. (2017). Waktu Berkualitas Bersama Anak.Sahabatkeluarga.Kemdikbud.Go.Id.

https://sahabatkeluarga.kemdikbud.go.id/laman/uploads/Dokumen/4483_201702-13/Waktu Berkualitas Bersama Anak.pdf

Prayitno, Irwan.(2010). Anakku penyejuk Hatiku. Jakarta: Pustaka Tarbiatuna

Rahayuningtyas F. (2012). Hubungan antara asupan serat dan faktor lainnya dengan status gizi lebih pada siswa SMPN 115 Jakarta Selatan Tahun 2012 [Skripsi]. Jakarta: Fakultas Kesehatan Masyarakat, Universitas Indonesia.

Relda. (2013). Gambaran Durasi Tidur Pada Remaja dengan Keleihan Berat Badan. Jurnal EBiomedik, 1, 849-853.

Worldometers.info. (2020). COVID-19 Coronavirus Pandemic. Www.Worldometers.Info. https://www.worldometers.info/coronavirus 